\title{
BIOFILM FORMATION ON BIOMATERIALS USED IN HERNIA SURGERY
}

\author{
POWSTAWANIE BIOFILMU NA BIOMATERIAŁACH STOSOWANYCH \\ W CHIRURGII PRZEPUKLIN
}

\author{
${ }^{1}$ Department of General Surgery and Transplantology, Ludwik Rydygier College of Medicine in Bydgoszcz, \\ Nicolaus Copernicus University in Torun, Poland \\ Head: Zbigniew Włodarczyk prof. \\ ${ }^{2}$ Department of Nutrition and Dietetics, Ludwik Rydygier College of Medicine in Bydgoszcz, \\ Nicolaus Copernicus University in Torun, Poland \\ Acting Head: Justyna Przybyszewska PhD \\ ${ }^{3}$ Department of Plant Physiology, Genetics and Biotechnology of the Warmia-Mazury University in Olsztyn, Poland \\ Head: Ryszard Górecki prof.
}

\section{S u m m a r y}

Deep surgical site infection (DSSI) in patients undergoing hernioplasty with implantation of biomaterials is a complication taking place with biofilm formation. Despite the indicated increase in the frequency of isolation of $S$. aureus and E. coli bacteria as etiological factors of DSSI, there have been few studies published so far that evaluated biofilm formation by these microorganisms on the surface of different biomaterials.

The aim of this study was to evaluate and compare biofilm formation on the surface of biomaterials used in hernia surgery by clinical isolates of $S$. aureus and $E$. coli.

70 strains of $S$. aureus and $E$. coli were used; they differed in chromosomal DNA within the species. The evaluation of biofilm formation on the surface of the monofilament polypropylene mesh, multifilament mesh (polypropylene, polyester and composite) and a patch of expanded polytetrafluoroethylene was made using qualitative and quantitative methods and by means of a scanning electron microscope.

The strains differ in terms of biofilm formation within the species. Strains of $S$. aureus formed a biofilm more strongly than E. coli. The investigated strains formed biofilm stronger on the surface of the multifilament implants than on polypropylene monofilament mesh.

Formation of biofilm by clinical isolates of S. aureus and E. coli on the surface of biomaterials used in hernia surgery varies depending on the strain and species of bacteria as well as the structure and the hydrophobicity of biomaterial.
Głębokie zakażenie miejsca operowanego (GZMO) u pacjentów poddanych hernioplastyce $z$ implantacją biomateriału jest powikłaniem przebiegającym $\mathrm{z}$ powstaniem biofilmu. Mimo, że notowany jest wzrost częstości izolacji bakterii $S$. aureus i E. coli jako czynników etiologicznych GZMO, dotychczas ukazały się nieliczne prace, w których oceniano tworzenie biofilmu przez te drobnoustroje na powierzchni różnych biomateriałów.
Celem pracy była ocena i porównanie tworzenia biofilmu na powierzchni biomateriałów stosowanych w chirurgii przepuklin przez izolaty kliniczne $S$. aureus i E. coli.

Użyto po 70 szczepów $S$. aureus i $E$. coli, izolowanych od różnych pacjentów hospitalizowanych w 3 klinikach chirurgii, różniących się wzorem DNA chromosomalnego w obrębie gatunku. Ocenę tworzenia biofilmu na powierzchni monofilamentowej siatki polipropylenowej, multifilamentowych siatek (polipropylenowej, poliestrowej i kompozytowej) oraz lacie $\mathrm{z}$ ekspandowanego politetrafluoroetylenu 
wykonano metodą jakościową, ilościową oraz z użyciem skaningowego mikroskopu elektronowego.

Szczepy różniły się zdolnością do tworzenia biofilmu w obrębie gatunku. Szczepy $S$. aureus tworzyły biofilm silniej niż pałeczki $E$. coli. Badane izolaty tworzyły biofilm silniej na powierzchni implantów multifilamentowych niż na monofilamentowej siatce polipropylenowej.

Tworzenie biofilmu przez izolaty kliniczne $S$. aureus i E. coli na powierzchni biomateriałów stosowanych chirurgii przepuklin różni się $\mathrm{w}$ zależności od szczepu i gatunku bakterii, struktury oraz hydrofobowości biomateriału.

Key words: biofilm, hernia, implant, deep surgical site infection

Słowa kluczowe: biofilm, przepuklina, implant, głębokie zakażenie miejsca operowanego

\section{INTRODUCTION}

Deep surgical site infection (DSSI) including biomaterials used in hernia surgery is a complication taking place along with biofilm formation, which is one of the reasons for the chronic course [1, 2]. Although the main etiological factors of DSSI in patients undergoing hernioplasty with implantation of biomaterials are $S$. aureus and $E$. coli bacteria $[1,2,3]$, few studies have been published so far in which formation of a biofilm by these microorganisms on various implants was evaluated $[4,5,6,7,8]$. The use of different test methods and different biomaterials makes comparison of presented results difficult, and sometimes impossible [4, 5, 6, 7, 8]. Available publications are based on results of research conducted on the reference strains and individual clinical isolates $[4,5,6,7,8]$. Reference strains may differ in ability to form biofilm as compared to strains isolated in the clinical conditions, and clinical isolates of a given species may differ in properties. It is therefore appropriate to carry out a research using a larger and a comparable number of clinical isolates of the $S$. aureus and $E$. coli species.

The aim of this study was to evaluate and compare biofilm formation on the surface of biomaterials used in hernia surgery by clinical isolates of $S$. aureus and E. coli.

\section{MATERIAL AND METHODS}

Bacterial strains. $70 \mathrm{~S}$. aureus strains and $70 \mathrm{E}$. coli strains, differing in chromosomal DNA patters within the species, were used, which was verified in the preliminary studies with the use of pulsed-field gel electrophoresis. The bacteria were obtained from the Department of Microbiology of Ludwik Rydygier Collegium Medicum in Bydgoszcz and the Nicolaus Copernicus University in Torun, and were isolated in the years 2008-2009 from wound swabs and pus samples from different patients treated at the Department of General and Endocrine Surgery, Department of General and Vascular Surgery and
Department of General Surgery and Transplantation of the Dr. Anthony Jurasz University Hospital No. 1 in Bydgoszcz. The strains were stored in brain heart infusion (BHI, Becton Dickinson, Sparks, USA) supplemented with $15 \%$ glycerol (POCH S.A., Gliwice, Poland) at the temperature of $-70{ }^{\circ} \mathrm{C}$.

Biomaterials. Sterile biomaterial fragments of size of $2 \mathrm{~cm} \mathrm{x} 1 \mathrm{~cm}$ (Table I) were examined.

Table I. The evaluated biomaterials Tabela I. Badane biomateriaty

\begin{tabular}{|c|c|c|c|}
\hline $\begin{array}{l}\text { Name } \\
\text { Nazwa }\end{array}$ & $\begin{array}{c}\text { Manufacturer } \\
\text { Producent }\end{array}$ & $\begin{array}{l}\text { Composition } \\
\text { Skład }\end{array}$ & $\begin{array}{c}\text { Abbreviation } \\
\text { Skrót }\end{array}$ \\
\hline Optomesh & $\begin{array}{c}\text { Tricomed, Łódź, } \\
\text { Poland }\end{array}$ & $\begin{array}{c}\text { Monofilament polypropylene mesh } \\
\text { Monofilametowa siatka } \\
\text { polipropylenowa }\end{array}$ & MonoPP \\
\hline Dallop PP & $\begin{array}{c}\text { Tricomed, Łódź, } \\
\text { Poland }\end{array}$ & $\begin{array}{c}\text { Multifilament polypropylene mesh } \\
\text { Multifilamentowa siatka } \\
\text { polipropylenowa }\end{array}$ & MultiPP \\
\hline Mersilene & $\begin{array}{l}\text { Ethicon, } \\
\text { Norderstedt, } \\
\text { Germany }\end{array}$ & $\begin{array}{c}\text { Multifilament polyester mesh } \\
\text { Multifilamentowa siatka poliestrowa }\end{array}$ & MultiPE \\
\hline Vypro & $\begin{array}{l}\text { Ethicon, } \\
\text { Norderstedt, } \\
\text { Germany }\end{array}$ & \begin{tabular}{|c|} 
Multifilament polyglactin fiber/ \\
multifilament polypropylene fiber \\
Multifilamentowa nić \\
poliglaktynowa/ multifilamentowa \\
nić polipropylenowa \\
\end{tabular} & PG/PP \\
\hline $\begin{array}{l}\text { Dual } \\
\text { Mesh }\end{array}$ & \begin{tabular}{|l} 
W.L. Gore, \\
Flagstaff, USA
\end{tabular} & $\begin{array}{c}\text { Expanded polytetrafluoroethylene } \\
\text { patch } \\
\text { Łata z ekspandowanego } \\
\text { politetrafluoroetylenu }\end{array}$ & ePTFE \\
\hline
\end{tabular}

Evaluation of biofilm formation. The study was performed with the use qualitative method $[9,10]$, quantitative method [11] and scanning electron microscopy (SEM) [12].

The qualitative study used the reaction of reduction of colourless 2,3,5-triphenyl tetrazolium chloride (TTC) to red formazan conducted by metabolically active bacteria $[9,10]$. Sterile biomaterial fragments were placed in tubes containing $4 \mathrm{ml}$ of trypticase soy broth (TSB, Becton Dickinson, Sparks, USA) with the bacterial suspension of density of 0,5 according to MacFarland scale. Next, the samples were incubated in an aerobic atmosphere at $37^{\circ} \mathrm{C}$ for 72 hours, replacing the medium with sterile one every 24 hours [9, 10]. Fragments of biomaterials, after 72-hour incubation in 
TSB medium with bacterial suspension of density of 0.5 as per MacFarland scale, were washed with $0.9 \%$ phosphate buffered saline solution (PBS, BTL, Łódź, Poland) of $\mathrm{pH} 7.2$ and placed in $4 \mathrm{ml}$ of sterile TSB medium containing $20 \mu \mathrm{l} 1 \%$ of TTC (POCH S.A., Gliwice, Poland) solution. After 24-hour incubation of samples at $37^{\circ} \mathrm{C}$ in the aerobic atmosphere, the TTC reduction ratio (biofilm formation) was assessed according to the scale as follows: 0 - no TTC reduction TTC (no biofilm formation or fragment of sterile mesh), 1 - small pinking points on implant surface (weak biofilm formation), 2 - pinking of the entire surface of the implant (strong biofilm formation), 3 redness of the whole surface of the implant, and the turbidity and red colour of the medium (very strong biofilm formation). The test was performed three times for each strain. The control was a sterile piece of biomaterial on sterile TSB medium.

Quantitative evaluation of biofilm formation was performed by a modified method used by Saygun et al. [11]. Fragments of biomaterials, after 72-hour incubation in TSB medium with bacterial suspension of density of 0.5 as per MacFarland scale and in sterile TSB medium (control) were washed with PBS of $\mathrm{pH}$ 7.2 and shaken $(1100 \mathrm{rpm})$ in $1 \mathrm{ml}$ of $0.5 \%$ saponin solution (Fluka, Steinheim, Germany) for 2 minutes [13]. Serial 10-fold dilutions of the resulting suspension were made and $100 \mu$ l thereof were placed on three Petri dishes with trypticase soy agar (TSA, Becton Dickinson, Sparks, USA) for each dilution. Then, they were incubated for 24 hours at $37^{\circ} \mathrm{C}$ in an aerobic atmosphere, and the result (the average of three measurements for a given dilution) were presented as the number of units forming colonies per $1 \mathrm{ml}$ of suspension $\left(\mathrm{CFU} \mathrm{x} \mathrm{ml} \mathrm{m}^{-1}\right.$ ). The results exceeding the range of 30-300 colonies/plate were not taken into account, as well as when the result was merged or semi-merged growth [13].

Evaluation of biofilm formation with the use SEM was performed by modified method described by Araujo et al. [12]. Randomly selected fragments of biomaterials, after 72-hour incubation in TSB medium with bacterial suspension of density of 0,5 per MacFarland scale and in sterile TSB medium (control) were washed with PBS of $\mathrm{pH} 7.2$ and fixed in $2.5 \%$ glutaraldehyde solution (POCH S.A., Gliwice, Poland) in $0.1 \mathrm{M}$ phosphate buffer of $\mathrm{pH} 7.4$ for 48 hours at $4^{\circ} \mathrm{C}$. The samples were then washed twice for 20 minutes at room temperature in phosphate buffer and dehydrated in ethanol at increasing concentrations of $30,50,70,80$ and $96 \%$ for 10 mins and twice in $99.8 \%$ ethanol (POCH S.A., Gliwice, Poland) for 30 minutes. After dehydration, biomaterials were transferred to a solution of hexamethyldisilazane (HMDS, Polysciences GmbH, Baden-Wurttenberg, Germany) for 45 minutes and then dried at room temperature. The dried material was placed on copper tables and gold coated in argon atmosphere in an ionic coater (Fine Coater, JCF-1200, JEOL, Tokyo, Japan). After transferring the samples to a scanning electron microscope column (JSM-5310LV, JEOL, Tokyo, Japan), the test was performed at the voltage of $20 \mathrm{kV}$ [12]. The results are analysed and recorded using the NSS Version 3.0 programme (Thermo Fisher Scientific Inc, Waltham, USA).

Statistical analysis. Statistical analysis was performed using 10.0 Statistica (StatSoft Poland) software. The correlation of qualitative variables was assessed using non-parametric $\chi^{2}$ test. To describe the quantitative variables, median was used. The statistical analysis for quantitative variables with distribution different from normal distribution was performed using non-parametric tests: Mann-Whitney test for independent samples and ANOVA Friedman test for dependent samples. The statistical analysis of differences between individual groups was performed using Dunn's post hoc test. Test probability of $\mathrm{p} \leq 0.05$ was assumed to be statistically significant.

\section{RESULTS}

Qualitative evaluation of biofilm formation. All strains of $S$. aureus and E. coli formed biofilm on the surface of biomaterials. The highest percentage of S. aureus $(48.6 \%)$ and E. coli $(25.7 \%)$ strains, forming a biofilm very strongly, was observed on the MultiPE surface, while the lowest $(10.0 \%$ for $S$. aureus and $5.7 \%$ for E. coli) was observed on MonoPP surface (Fig. 1-2).

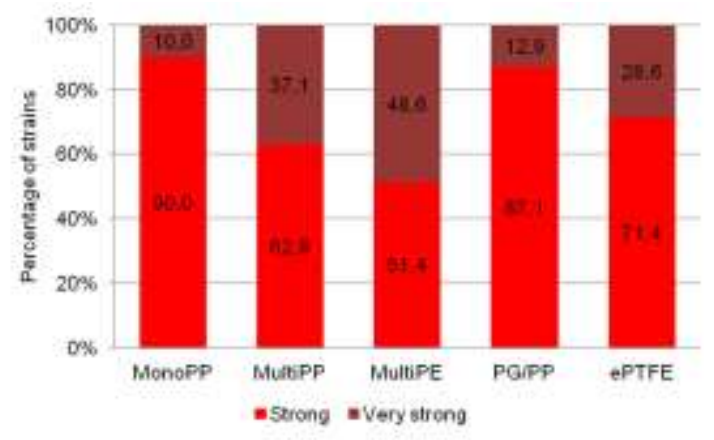

Fig. 1. Biofilm formation by S. aureus strains $(n=70)$ on tested biomaterials - evaluation using qualitative ethod (table I designation)

Ryc. 1. Tworzenie biofilmu przez szczepy S. aureus $(n=70)$ na badanych biomateriałach - ocena metoda jakościowa (oznaczenia w tabeli I) 
The difference between formation of biofilm by $S$. aureus and $E$. coli strains and the type of material was statistically significant $(\mathrm{p}<0.0001$ and $\mathrm{p}<0.005$, respectively). The tested isolates of $S$. aureus and $E$. coli formed biofilm the strongest on the MultiPE surface, and the weakest on the MonoPP surface (Fig. 1-2). S. aureus strains formed biofilm much stronger as compared to $E$. coli strains on the surface of the tested materials, except for PG/PP ( $<<0.05)$.

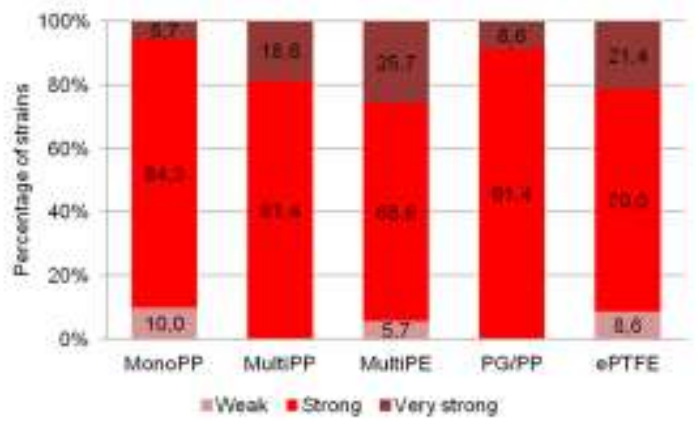

Fig. 2. Biofilm formation by E. coli strains $(n=70)$ on tested biomaterials - evaluation using qualitative method (table I designation)

Ryc. 2. Tworzenie biofilmu przez szczepy E. coli $(n=70)$ na badanych biomaterialach - ocena metoda jakościowa (oznaczenia $w$ tabeli I)

Quantitative evaluation of biofilm formation. The following was isolated from the biofilm formed by the isolates of $S$. aureus on the surface of biomaterials: $5.5 \times 106$ for MonoPP, $1.8 \times 10^{7}$ for MultiPP, $3.0 \times 10^{7}$ for MultiPE, $7.2 \times 10^{6}$ for PG/PP and $1.5 \times 10^{7} \mathrm{CFU} \mathrm{x} \mathrm{ml}{ }^{-1}$ for ePTFE (Fig. 3). However, the following was isolated from biofilm formed by $E$. coli bacili: $1.9 \times 10^{6}$ for MonoPP, $8.8 \times 10^{6}$ for MultiPP, $9.6 \times 10^{6}$ for MultiPE, $5.3 \times 10^{6}$ for PG/PP and $5.5 \times 10^{6}$ CFU $x$ ml$^{-1}$ for ePTFE (Fig. 4). Differences in obtained values both among isolates of $S$. aureus and $E$. coli were statistically significant $(p<0.0001)$. From the biofilm produced by isolates of $S$. aureus on the surface of all tested biomaterials there were significantly more $\mathrm{CFU} \mathrm{x} \mathrm{ml}{ }^{-1}$ isolated than in the case of biofilm formed by $E$. coli bacilli (p<0.05).

Based on the biofilm by $S$. aureus formed on the MonoPP surface and PG/PP surface, there was significantly less CFU $\mathrm{x} \mathrm{ml}^{-1}$ than from biofilm formed on the other biomaterials tested $(\mathrm{p}<0.01)$. There were no other statistically significant differences in biofilm formation by $S$. aureus on MonoPP and $\mathrm{PG} / \mathrm{PP}$ surfaces. Differences in the number of CFU $\mathrm{x} \mathrm{ml}^{-1}$ isolated from the biofilm formed on the MultiPP and
MultiPE, as in the case of MultiPP and ePTFE and MultiPE and ePTFE were not statistically significant

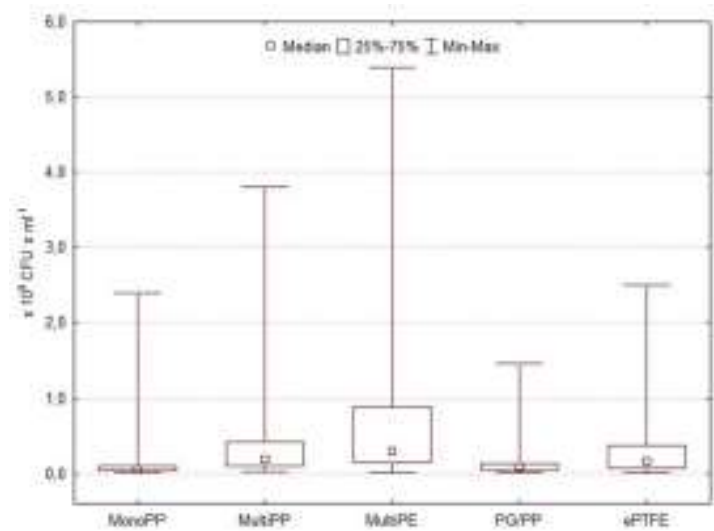

Fig. 3. Biofilm formation by $S$. aureus strains $(n=70)$ on tested biomaterials - evaluation using quantitative method (table I designation)

Ryc. 3. Tworzenie biofilmu przez szczepy S. aureus $(n=70)$ na badanych biomateriałach - ocena metoda ilościowa (oznaczenia $w$ tabeli I)

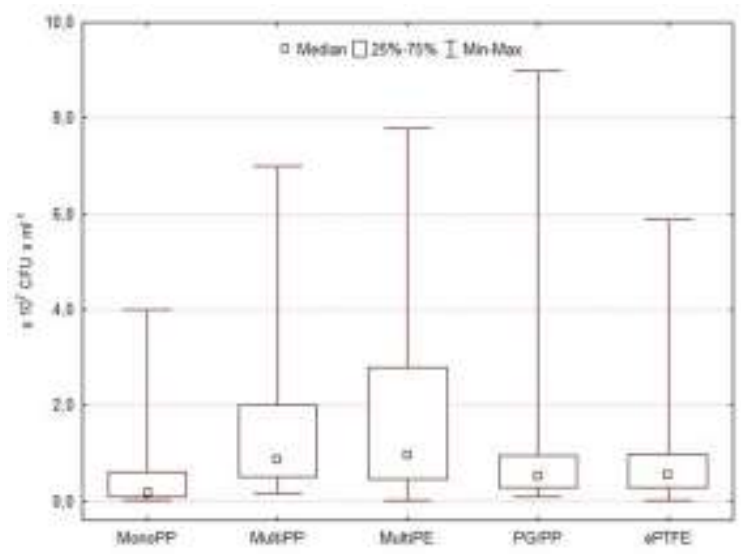

Fig. 4. Biofilm formation by E. coli strains $(n=70)$ on tested biomaterials - evaluation using quantitative method (table I designation)

Ryc. 4. Tworzenie biofilmu przez szczepy E. coli $(n=70)$ na badanych biomateriałach - ocena metoda ilościowa (oznaczenia w tabeli I)

Based on the biofilm by $E$. coli formed on the MonoPP surface and PG/PP surface, there was significantly less CFU $\mathrm{x} \mathrm{ml}^{-1}$ than from biofilm formed on the other biomaterials tested $(\mathrm{p}<0.01)$. Based on the biofilm by $E$. coli formed on the PG/PP surface, there was significantly less CFU $\mathrm{x} \mathrm{ml}{ }^{-1}$ than from biofilm formed on the MultiPP and Multi PE surfaces $(p<0.01)$. There were no statistically significant differences in the number of CFU x ml ${ }^{-1}$ obtained from biofilm by $E$. coli formed on PG/PP and ePTFE surfaces, as in the case of MultiPP and MultiPE, MultiPP and ePTFE and MultiPE and ePTFE. 

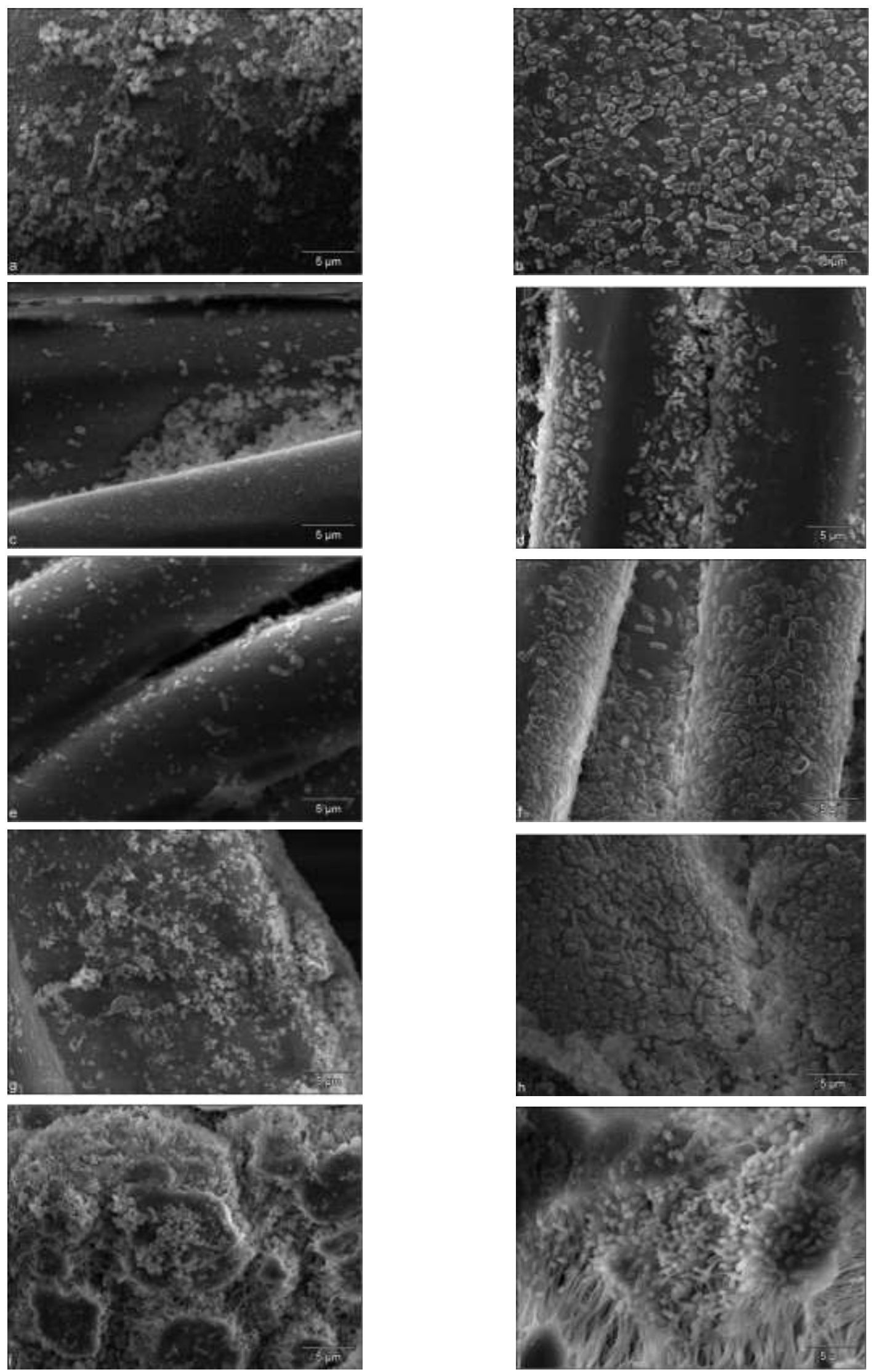

Fig. 5. Biofilm on the surface of tested biomaterials, SEM - 3500x magnification; S. aureus biofilm: a - MonoPP, $c-M u l t i P P$, $e$-MultiPE, $g$ - PG/PP, $i$-ePTFE; E. coli biofilm: $b$-MonoPP, $d$-MultiPP, $f$-MultiPE, $h$ - PG/PP, $j$ - ePTFE (table I designation)

Ryc. 5. Biofilm na powierzchni badanych biomateriałów; SEM - powiększenie 3500x; biofilm S. aureus: a - MonoPP, cMultiPP, $e-$ MultiPE, $g-P G / P P, i-e P T F E$; biofilm E. coli: $b-M o n o P P, d-M u l t i P P, f-M u l t i P E, h-P G / P P, j-$ ePTFE (oznaczenia $w$ tabeli I 
SEM. Microorganisms covered the surface of biomaterials tested not uniformly (Fig. 5a-j). There were areas without any microorganisms (Fig. 5a-b, $5 \mathrm{i}-\mathrm{j}$ ) and clusters of bacteria, especially in the places of crossing fibres and in niches between fibres (Fig. $5 c-h)$. Differences were found in the construction of multifilament implants. MultiPE mesh fibres had the smallest diameter among the tested biomaterials. The diameter of fibres of the polypropylene component of PG/PP mesh fibres was greater than of MultiPP implant fibres.

\section{DISCUSSION}

The work shows that the formation of a bacterial biofilm on the surface of biomaterials used in hernia surgery depends on the properties of microorganisms and the synthetic material. Furthermore, differences were found between formation of biofilm by $S$. aureus and $E$. coli bacteria, both within species and between these species.

Bacterial biofilm formation was analysed by qualitative and quantitative methods and using SEM. Due to the subjective nature of method using the reaction of reduction TTC, the results obtained by qualitative method were compared with the results of the quantitative study. In order to evaluate the morphology of bacteria forming the biofilm and the structure of implants, SEM was used.

Own study has shown the ability to form biofilm by all isolates of $S$. aureus and E. coli species, which demonstrates the wide prevalence of this feature among strains of these species obtained from the hospital environment. The isolates differed in terms of characteristics both within species and between species. Similar observations were made by other researchers [4,8]. Engelsman et al. [4] found that Gram-positive bacteria form a biofilm stronger than Gram-negative bacteria. Own study has found that strains of $S$. aureus formed biofilm stronger that $E$. coli strains on the surface of implants tested. What, presumably, had an impact on stronger biofilm formation by $S$. aureus as compared to $E$. coli was staphylococci hydrophobicity. S. aureus bacteria are characterized by higher hydrophobicity than E. coli [14], and microorganisms of higher hydrophobicity adhere to the surface stronger [15].

Isolates of $S$. aureus and $E$. coli, used in own study, formed biofilm significantly stronger on the surface of the multifilament (polypropylene and polyester) implants than on polypropylene monofilament mesh. The structure of tested biomaterials influenced the results. Multifilament implants promote the formation of biofilm, which results from the larger surface area of the biomaterial and the presence of niches between fibres [4]. Differences in the structure of mesh were also responsible for a significantly stronger biofilm formation on the multifilament surface of polypropylene mesh than on the surface of the composite mesh. Both studies conducted by other authors [16] as own study showed that fibres of multifilament polypropylene implant have a smaller diameter than the polypropylene fibres of the composite mesh. In addition, there is lesser number of niches between fibres of a composite implant than between fibres of multifilament polypropylene mesh [16]. These differences in the structure of biomaterials are the reason of stronger adhesion of $S$. aureus to the surface of multifilament polypropylene mesh than to the composite implant [16].

$S$. aureus and E. coli strains formed biofilm significantly stronger on the surface of the ePTFE patch than on the surface of the monofilament polypropylene mesh. This was probably due to the higher hydrophobicity of the ePTFE implant than in case of polypropylene. The hydrophobicity of biomaterial promotes bacterial adhesion and biofilm formation [4, 17]. These observations correlate with results of studies by Gungor et al. [18], who found that $S$. aureus and E. coli strains adhere to the surface of the ePTFE patch much stronger than to monofilament polypropylene mesh. With regard to $S$. aureus, Harrell et al. obtained different results [19]. It is possible that differences in the results obtained were due to the use of different incubation times by individual researchers. Harrell et al. [19] conducted incubation of biomaterial samples in the bacterial suspension for 1 hour, while Gungor et al. [18] did it for 16 hours.

Examination with SEM showed uneven distribution of bacteria on the surface of biomaterials, which could be due to the detachment of microorganisms from the surface of the implants due to their high concentration in a given location. This hypothesis is supported by the red trypticase soy broth observed in the method, providing for the transfer of bacteria from the surface of the biomaterial to the base level. The same observations were made by Różalska et al. [10] who, using the qualitative method, evaluated formation of biofilm on the surface of catheters. 
Both $S$. aureus and E. coli isolates gathered in the place of crossing of fibres and in the niches between the fibres. Results of own study are consistent with observations of other researchers $[4,20]$. It is believed that the reason for the presence of clusters of microorganisms in these locations is the large area conducive to bacterial adhesion $[4,20]$. It is possible that the accumulation of micro-organisms in the location of fibre crossing and the niches between the fibres are the cause of implant deformation observed in the course of DSSI covering the implanted biomaterial [21].

\section{CONCLUSIONS}

Formation of biofilm by clinical isolates of $S$. aureus and $E$. coli on the surface of biomaterials used in hernia surgery varies depending on the strain and species of bacteria as well as the structure and hydrophobicity of biomaterial.

The work was co-financed from the resources of the European Social Fund and National Budget in terms of Integrated Operational Programme of Regional Development, Measure 2.6. 'Regional Innovation Strategies and knowledge transfer', by the European Union in terms of European Social Fund "Nicolaus Copernicus University Collegium Medicum development programme" from the resources of Nicolaus Copernicus University (UMK) 06/2009 grant and the departmental resources.

\section{ACKNOWLEDGEMENTS}

The authors wish to thank Professor Eugenia Gospodarek, Head of the Department of Microbiology of the Ludwik Rydygier College of Medicine of the Nicolaus Copernicus University for making this study possible.

\section{REFERENCES}

1. Dietz UA, Spor L, Germer CT. Management of meshrelated infections. Chirurg 2011; 82; 208-217

2. Tolino MJ, Tripoloni DE, Ratto $\mathrm{R}$ et al. Infections associated with prosthetic repairs of abdominal wall hernias: pathology, management and results. Hernia, 2009; 13: 631-637

3. Ahmad S, Mufti TS, Zafar A et al. Conservative management of mesh site infection in ventral hernia repair. J Ayub Med Coll Abbottabad 2007; 19: 75-77
4. Engelsman AF, van der Mei HC, Busscher HJ et al. Morphological aspects of surgical meshes as a risk factor for bacterial colonization. Br J Surg 2008; 95: 1051-1059

5. Halaweish I, Harth K, Broome AM et al. Novel in vitro model for assessing susceptibility of synthetic hernia repair meshes to Staphylococcus aureus infection using green fluorescent protein-labeled bacteria and modern imaging techniques. Surg Infect (Larchmt) 2010; 11: 449-454

6. Daghighi S, Sjollema J, Jaspers V et al. Persistence of a bioluminescent Staphylococcus aureus strain on and around degradable and non-degradable surgical meshes in a murine model. Acta Biomater 2012; 8:3991-3996

7. Engelsman AF, van Dam GM, van der Mei HC et al. In vivo evaluation of bacterial infection involving morphologically different surgical meshes. Ann Surg 2010; 251: 133-137

8. Parshikov VV, Chebotar IV, Khodak VA et al. In vitro studies of biofilms on the surface of synthetic macroporous endoprostheses for abdominal wall plasty. Sovrem Technol Med 2012; 1: 15-20

9. Gallimore B, Gagnon RF, Subang R et al. Natural history of chronic Staphylococcus epidermidis foreign body infection in a mouse model. J Infect Dis 1991; 164: 12201223

10. Różalska B, Sadowska $B$, Więckowska $M$ et al. Wykrywanie biofilmu bakteryjnego na biomateriałach medycznych. Med Dosw Mikrobiol 1998; 50: 115-122

11. Saygun O, Agalar C, Aydinuraz K et al. Gold and goldpalladium coated polypropylene grafts in a S. epidermidis wound infection model. J Surg Res 2006; 131: 73-79

12. Araujo JC, Téran FC, Oliveira RA et al. Comparison of hexamethyldisilazane and critical point drying treatments for SEM analysis of anaerobic biofilms and granular sludge. J Electron Microsc (Tokyo) 2003; 52: 429-433

13. Kwiecińska-Piróg J, Bogiel $\mathrm{T}$, Gospodarek E. Porównanie dwiema metodami tworzenia biofilmu przez pałeczki Proteus mirabilis na powierzchni różnych biomateriałów. Med. Dosw Mikrobiol 2011; 63:131-138

14. Dickson JS, Koohmaraie M. Cell surface charge characteristics and their relationship to bacterial attachment to meat surfaces. Appl Environ Microbiol 1989; 55: 832-836

15. van Loosdrecht MC, Lyklema J, Norde W et al. The role of bacterial cell wall hydrophobicity in adhesion. Appl Environ Microbiol 1987; 53: 1893-1897

16. Aydinuraz $\mathrm{K}$, Ağalar $\mathrm{C}$, Ağalar $\mathrm{F}$ et al. In vitro $S$. epidermidis and $S$. aureus adherence to composite and lightweight polypropylene grafts. J Surg Res 2009; 157: e79-86

17. Hogt AH, Dankert J, de Vries JA et al. Adhesion of coagulase-negative staphylococci to biomaterials. J Gen Microbiol 1983; 129: 2959-2968

18. Gungor B., Esen Ş., Gök A. et al. Comparison of the adherence of $E$. coli and $S$. aureus to ten different prosthetic mesh grafts: in vitro experimental study. Indian J Surg 2010; 72: 226-231 
19. Harrell A.G., Novitsky Y.W., Kercher K.W et al. In vitro infectability of prosthetic mesh by methicillin-resistant Staphylococcus aureus. Hernia 2006; 10: 120-124

20. Bellón JM, G-Honduvilla N, Jurado F et al. In vitro interaction of bacteria with polypropylene/ePTFE prostheses. Biomaterials 2001; 22: 2021-2024

21. Mamy L, Letouzey V, Lavigne JP et al. Correlation between shrinkage and infection of implanted synthetic meshes using an animal model of mesh infection. Int Urogynecol J Pelvic Floor Dysfunct 2011: 22: 47-52

\section{Address for correspondence:}

Adrian Reśliński PhD

Department of General Surgery and Transplantology

Nicolaus Copernicus University in Torun

Ludwik Rydygier College of Medicine in Bydgoszcz

M. Skłodowskiej-Curie 9 Str.

85-094 Bydgoszcz, Poland

tel. 004852 585-47-30

fax 004852 585-40-16

e-mail: bigar@wp.pl

Received: 6.06.2014

Accepted for publication: 2.09.2014 